\title{
Population structure, spatial distribution and phenology of Anacardium humile A. St.-Hil. (Anacardiaceae) in cerrado stricto sensu ${ }^{1}$
}

\author{
๑Diego Guimarães de Sousa ${ }^{2,4}$ and Hélida Ferreira da Cunha ${ }^{3}$
}

Received: 7.11.2017; accepted: 11.06.2018

\begin{abstract}
Population structure, spatial distribution and phenology of Anacardium humile A. St.-Hil. (Anacardiaceae) in cerrado stricto sensu). This study determined the size structure, spatial distribution, and phenology of individuals from a population of Anacardium humile A. St.-Hil. in a cerrado stricto sensu area. Four sample plots $(100 \times 100 \mathrm{~m}$ each $)$ were randomly selected in the Quilombola Kalunga land. Within the plots, we counted the number of individuals and measured the height, basal diameter, number of tree branches and recorded their location and the presence of rocky outcrops. For the phenological analysis, sixteen individuals were monitored between May 2016 and April 2017. A total of 417 individuals were inventoried, which resulted in an average density of 104.25 ind ha ${ }^{-1}( \pm 60.35)$. The abundance of individuals was higher in the rocky outcrops and with an aggregate spatial distribution. The population is self-regenerating. Phenological changes were concentrated in the dry season and were influenced by lower precipitation rates, maximum temperature, and relative humidity.
\end{abstract}

Keywords: aggregate, cajuí, Brazilian savanna, demography, flowering

RESUMO - (Estrutura populacional, distribuição espacial e fenologia de Anacardium humile A. St.-Hil. (Anacardiaceae) em cerrado stricto sensu). Este estudo analisou a estrutura de tamanho, a distribuição espacial e a fenologia dos indivíduos de uma população de Anacardium humile A. St.-Hil. em cerrado sentido restrito. Foram alocadas aleatoriamente quatro parcelas $(100 \times 100 \mathrm{~m}$ cada $)$ na terra Quilombola Kalunga. Dentro das parcelas cada indivíduo foi contabilizado e teve mensurada a altura, diâmetro basal, quantidade de ramos e anotações quanto a sua localização e a presença de afloramentos rochosos. Para a fenologia, dezesseis indivíduos foram monitorados entre maio de 2016 a abril de 2017. Foram inventariados 417 indivíduos que resultaram na densidade média de 104.25 ind ha- $^{-1}( \pm 60,35)$. A abundância de indivíduos foi maior nos afloramentos rochosos e o padrão de distribuição espacial foi do tipo agregado. A população é auto-regenerativa. As alterações fenológicas concentraram no período seco e foram influenciadas pelas menores taxas de precipitação, temperatura máxima e umidade relativa do ar.

Palavras-chave: agregado, cajú, savana brasileira, demografia, floração

\section{Introduction}

The high deforestation rates in the Cerrado biome (IBAMA 2015) and the low number of protected areas threaten the maintenance of its environmental services and the conservation of its biodiversity (Garcia et al. 2011, Paiva et al. 2015). Regarding its flora, there are over 12000 species in the Cerrado, which about $40 \%$ are endemic (REFLORA/CNPQ 2017). Due to the anthropic conversion of natural areas in the Cerrado, most of these endemic species are threatened even before knowing the structure and spatial distribution of most of their populations.

The population structure of a species is a result of action and interactions of evolutionary mechanisms such as the variation in the gene pool and its organization, the spatial distribution of genotypes, the reproductive system and ecological mechanisms such as pollination, dispersion, predation, mortality and regeneration (Hutchings 1997, Dale 1999).

1. Parte da Dissertação de Mestrado do primeiro Autor

2. Instituto Brasileiro de Meio Ambiente e dos Recursos Naturais Renováveis, Rua 229, 95, Setor Universitário, 74605-090 Goiânia, $\mathrm{GO}$, Brasil

3. Universidade Estadual de Goiás, Laboratório de Pesquisa Ecológica e Educação Científica, Rodovia Br-153, 3.105, Fazenda Barreiro do Meio, 75132-903 Anápolis, GO, Brasil

4. Autor para correspondência: diegoagro97@hotmail.com 
The structure analysis allows the understanding of which environmental factors are responsible for the population variations in time and space, and how each species interact with the environment (Oliveira et al. 2001). These studies can contribute to the species management, in the restoration of anthropized areas and in the establishment of areas for preservation when informing if the genetic variability and the size patterns of the remaining or implanted population are adequate for the maintenance of the local evolutionary processes (Schiavini et al. 2001, Fidelis et al. 2007, Frankham et al. 2008).

The analyses of population structure allow interferences in development of the population in the environment (Kowles \& Grant 1983), since the action of biotic and abiotic factors on their current and ancestral members affect the spatial arrangement and the age and genetic structures of its components (Hutchings 1997). The microenvironments in which the plants are inserted create a large variety of niches exerting influence over their performance and survival, and are directly related to the diversity of plant and animal species (Aidar 1992).

The size of a plant is fundamental, because for them is more interesting to reach a minimum size, reflecting the accumulation of nutrient reserves and exposure to better environmental conditions (water, light and nutrients), than reaching a certain age (Berg 2001), indicating its competitive performance in the environment. Individuals of the same age can present different sizes depending on their genetic potential and, especially, on the local abiotic conditions (Sposito $\&$ Santos 2001). Thus, in general, the plants survival and their subsequent growth depend more on size than on age (Gurevitch et al. 2009).

The studies on the spatial distribution of populations show how individuals disposition have an influence on the mating rate (Epperson 1989), affecting pollinators behavior and, consequently the reproductive success of plants (Dale 1999). The spatial distribution pattern is influenced by factors such as parental distribution, dispersion ways, predators and herbivorous, the presence suitable microsites (Hutchings 1997) and the occurrence of stochastic events and anthropic disturbances (Lundberg \& Ingvarsson 1998, Dale 1999).

There are three spatial distribution patterns presented by individuals of plant populations: random, uniform and aggregate (Dale 1999). The random distribution supports an environmental homogeneity leading to a non-selective behavior. The aggregate distribution indicates grouping of individuals in more suitable niches. And the uniform distribution indicates negative interactions of individuals (Ludwig \& Reynolds, 1988). In the Brazilian Cerrado several species have shown the aggregate pattern in different scales and locations (Oliveira et al. 1989, Meireles \& Luiz 1995, Hay et al. 2000, Resende et al. 2003, Souza \& Coimbra 2005, Costa 2006, Lima-Ribeiro 2007a, b, Lima-Ribeiro \& Prado 2007, Bernasol \& Lima-Ribeiro 2010, Bruzinga et al. 2013, Elias et al. 2013, Lopes et al. 2013, Souza-Leal \& Pedroso-deMoraes 2014), even though this pattern may change in degraded environments (Meira Junior et al. 2017).

The phenological study of plants is another scientific tool that allows the understanding of the ecology, dynamic and evolution of ecosystems (Fournier 1976). These studies can be performed in populations or communities, analyzing quantitatively (intensity of occurrence of the phenophases) and qualitatively (periods of occurrence of phenophases) (Fournier 1974). The phenology is directly related to environmental factors, such as climatic and edaphic, because they generally have influence on biological phenomenon (Morellato 1995, Arrigoni-Blanck et al. 1996). From it, it is possible to analyze the causes and the physiognomic manifestations of flowering phenomenon, fruiting, falling leaves and sprouting of plants throughout the year (Fournier 1976, Morellato 1991), contributing to the understanding of the vegetative and reproductive patterns of plants and animals that depend on them (Morellato 1995).

The phenological knowledge of Cerrado species is fundamental to developing restoration projects, native areas management, for the collection of fruits of commercially fruit species and in obtaining seeds for silvicultural purposes (Ribeiro et al. 1981, Araújo et al. 1987). It can also contribute to the productivity of agroforestry systems, pest control, management and conservation of plant communities and populations, and conservation units (Rego et al. 2007).

Despite of several studies involving ecology in the Cerrado, few of them regard the population structure and spatial distribution of the species (Lima-Ribeiro \& Prado 2007). For example, the "cajuí,, Anacardium humile A. St.-Hil., that despite belonging to a genus with many studies regarding the biology of its species, has few population information available (Grando 2009) and occasional phenological researches, addressed in the communities' context (Dalponte \& Lima 1999, Batalha \& Mantovani 2000, Weiser \& Godoy 2001). This lack of studies enables 
the initiation of researches in order to plan strategies for the preservation and use of the species (Carvalho et al. 2005).

The present study aimed to determine the population structure, spatial distribution and phenological pattern of A. humile in cerrado stricto sensu environment. We sought to answer the following questions: Does the presence of rocky outcrops in the environment alter the abundance patterns, spatial distribution, size and density of the individuals? Are individuals with more number of branches taller? Is the spatial distribution pattern of the population random? Is the population in dynamic equilibrium? As observed in other Cerrado species, do the population individuals show greater height investment? Do vegetative and reproductive phenomes have seasonal rhythms influenced by climatic variables?

\section{Material e methods}

Study area - This research was conducted in a cerrado stricto sensu environment, with forest fire history of five years. The experimental area is located inside the Quilombola community named Kalunga, municipality of Cavalcante, northern Goiás (geographic coordinates $13^{\circ} 36^{\prime} 09^{\prime \prime} \mathrm{S}$ e $\left.47^{\circ} 27^{\prime} 26^{\prime \prime} \mathrm{W}\right)$. The Kalunga territory is located in the Chapada dos Veadeiros, with altitude varying between $560 \mathrm{~m}$ and $1118 \mathrm{~m}$ (Fundação Grupo Boticário, 2011), the altitude is $1046 \mathrm{~m}$ in the plot 1 , $1013 \mathrm{~m}$ in the plot 2, $1017 \mathrm{~m}$ in the plot 3 and 1023 in the plot 4 . The climate is tropical savanna (KöppenGeiger classification), with two defined seasons, one rainy between October and April and another dry between May and September (Neiva et al. 2008). The mean annual precipitation varies from 1300 to 1500 $\mathrm{mm}$ and mean temperature is around $25^{\circ} \mathrm{C}$ (Fundação Grupo Boticário, 2011). The soil is sandy type with rocky outcrops and gravel, classified as Dystrophic Litholic Neosols (Fundação Grupo Boticário 2011, Embrapa 2006).

Study species - "Cajuí", Anacardium humile A. St.Hil. (Anacardiaceae), frequently occur in the cerrado stricto sensu and campo sujo. The plant is heliophilous and melliferous (Almeida et al. 1998), presenting medicinal and food potential, placed in the tropical fructiferous group (Carvalho et al. 2005). The species presents a subshrubby habit with underground stem (Almeida et al. 1998) and this small size makes the species more susceptible to anthropic actions of land use and damages by the flames of the fire during the fires than the common cashew tree (Anacardium occidentale L.) (Carvalho et al. 2005).
Its flowering takes place from July to September with fruiting occurring from August to October, with limited seed production due to low pollination and high predation by animals and insects (Ferrão 1995). The high ratio of $4: 1$ between male flowers and hermaphrodites (Almeida et al. 1998), the inability of some hermaphrodite flowers to turn into fruits, the tendency of pollen grains of the stamens to remain attached to the anther after dehiscence and the existence of only a fertile stamen in the staminate flowers are pointed out as reasons for the low pollination in the species (Ferrão 1995).

The true fruit is a reniform nut, with hard dry pericarp, brown color, reaching its final size even before the pedicel thicken and modifies in a berry shaped fruit (Barroso et al. 1999). The false fruits and fruits are valued by locals as food sources (Almeida et al. 1998).

Experimental Design and Inventory - For the study of population structure and spatial distribution, from May to June 2016, we delimited four plots of $100 \times 100 \mathrm{~m}(4 \mathrm{ha})$ to ensure representativeness, since the population of $A$. humile is inserted in an extensive area of the Cerrado. The plots were allocated in a minimum distance of approximately $90 \mathrm{~m}$ between them to guarantee proportionality and to avoid overlapping. Each plot was divided into 16 subplots of $25 \times 25 \mathrm{~m}$, where we performed a census of all individuals of $A$. humile.

Considering that the species present underground stem that and can bind nearby stems of the same plant (Rawitscher et al. 1943), the distinction between the individuals was performed by visualization of treetop area, which shows roughly circular outline (Lóppez-Naranjo 1975). In general, we considered distinct individuals those with a distance greater than $1 \mathrm{~m}$ between the ends of their crowns, with branches coming at the same point, visually configuring the unitary structure of shrub or subshrub.

For each inventoried specimen, we recorded the location parameters within the plot (coordinates $\mathrm{x}, \mathrm{y}$ ), total height and basal diameter (bd, measured $5 \mathrm{~cm}$ from soil) of the main branch (higher), quantity of secondary branches, and if it was present in environment with or without rocky outcrops.

For the phenological study, we selected 16 individuals within two of the implemented plots, totalizing 8 in each. The criteria for selecting the individuals were the location (being located in the central line of the plots) and the number of branches 
per individuals (having at least three branches, to mitigate the difference in size between individuals). Individuals were labeled and numbered sequentially. Observations and data collection were performed monthly for the emergence parameter of new leaves and eight times per month for the registration of floral buds phenophases, flowering (anthesis) and fruiting. Field observations were carried out from May 2016 to April 2017.

The intensity of leaf emergence phenomenon was estimated for each individual according to the methodology of Ribeiro \& Castro (1986), which is easy to apply in the field. The method recommends the following class intervals: $0=0 \%$ (absence of the phenomenon), $1=4 \%, 2=15 \%, 3=30 \%, 4=50 \%$, $5=70 \%, 6=85 \%, 7=96 \%$ and $8=100 \%$. For flowering and fruiting were counted the quantities of flower buds, flowers and fruits from all inflorescences emitted in up to three branches per plant sampled.

Analyses and statistical tests - To verify the influence of the areas with and without outcrops on the abundance of the individuals, chi-square trend tests were performed, at a significance level of 5\%. In each plot we observed an occupation of rock outcrops of $10 \%$ to $50 \%$ of the area, for example, in a $50 \%$ of its area covered by rock outcrops, we found $50 \%$ of the area without outcrops. In this way, we used the number of individuals inventoried in the environment with and without rocky outcrops and the proportional size of the area with rocky outcrops $(10 \%, 20 \%, 30 \%$ and $50 \%)$ and without rocky outcrops $(90 \%, 80 \%, 70 \%$ and $50 \%$ ) within each plot. The trend test (A) may be increasing $(\mathrm{A}>0)$, indicating, for example, that as the area with rocky outcrops inside the plots increases, there is an increase in the number of individuals inventoried, or decreasing $(\mathrm{A}<0)$, indicating inversely proportional relations between these variables. In order to test the influence of the rocky outcrops on the density of the individuals of $A$. humile, the number of individuals in the different environments in which they occurred was counted. The Wilcoxon-Mann-Whitney $\mathrm{U}$ test was used to compare the medians of density, height, basal diameter and number of branches per individual located in environments with and without rocky outcrops.

The Spearman correlation (Rho) was used to test whether the competition for light and space between the branches causes leads to greater growth in total height of the specimen. The analysis of the degree of association between the number of branches and the total height of the individuals will indicate the type of relation (positive, negative or indifferent) and the intensity between these variables.

The Morisita's Index (MI), used by Budke et al. (2004) and by Vasconcelos et al. (2011) was used here to know the spatial distribution pattern of the population, including the presence of rocky outcrops. The MI is the most indicated method to verify the spatial distribution pattern of individuals in each plot because it uses sample units (plots) and is slightly influenced by the size of the sample unit, presenting excellent detection qualities (Nascimento et al. 2001). The significance for the values calculated for the Morisita's Index (MI) was obtained by means of the chi-square test at a significance level of $5 \%$.

For the spatial distribution analysis of the individuals of $A$. humile were determined the Mclu and Muni, the upper and lower limits of the Morisita's Index for a random distribution and the Imst (Standardized Morisita's Index) (Hairston et al. 1971, Krebs 1999). If imor $>$ mclu the species has an aggregate spatial distribution, if imor $<$ muni, the spatial distribution pattern is regular. If Imst varies between -0.5 and 0.5 , the distribution is random, if it is less than -0.5 , the distribution is regular and if greater than 0.5 , the distribution is aggregate.

In order to evaluate the population size structure and infer about its stability and auto-regeneration capacity, the intervals of histograms classes of height and basal diameter of the individuals were defined by the formula $A / K$. In this formula, $A$ represents the range of the mean values (for height and basal diameter) and $K$ the number of class intervals defined by the Sturges algorithm: $K=1+3.3 \times \log . \mathrm{N}$, where $\mathrm{N}$ is the number of individuals sampled (Paixão 1993). A population in dynamic equilibrium, with autoregeneration capacity, will present a greater number of individuals in the first classes of total height and basal diameter, with abundance decreasing as the classes of these variables increases.

The population growth pattern was evaluated by using a simple linear regression, after transformation of the height and basal diameter data into $\log x+1$ and analysis of the hypsometric curve and its mathematical equation. The regression coefficient (b) served to indicate which of the variables was more important for population growth.

The ratio between height and basal diameter was also calculated according to the basal diameter classes presented in the histogram to evaluate the importance of these variables in individuals of different sizes. 
Significance was assessed using the Kruskal-Wallis $\mathrm{H}$ Test and posteriorly by Student-Newman-Keuls (SNK) test.

The descriptive statistics, correlation tests and regressions were performed in the Biostat program version 5.0 (Ayres et al. 2007), while the spatial distribution analyses were performed in the $\mathrm{R}$ program ( $\mathrm{R}$ Core Team 2017), using the vegan package (Oksanen et al. 2016).

For the analysis of the phenological data, two evaluation methods were applied, adapted from Bencker \& Morellato (2002):

Index or Percentage of Intensity (II), which aims to estimate the intensity of the phenophases: in case of emergence of new leaves, the intensity values obtained for all individuals were added to each month, according to class intervals of Ribeiro \& Castro (1986) and divided by the maximum possible value. The value was multiplied by 100 to convert it into a percentage, as well as the one adopted in the method of Fournier (1974). For the flower bud, flower and fruit data, the monthly value found for each parameter was summed, referring to all individuals sampled and divided by the total produced in the reproductive year. The value was also converted into percentage.

Activity Index (AI), or individuals' percentage, which consists of the presence or absence of phenophases by individuals. It has a quantitative aspect, indicating the percentage of individuals sampled that is manifesting a certain phenological event. This method estimates the existing synchrony between the individuals of a population (Morellato \& Leitão-Filho 1990).

The analysis of climatic influence on the occurrence of phenophases was performed according to França et al. (2017), with minor modifications. The monthly averages of maximum temperature, minimum temperature, mean temperature, relative humidity and insolation were obtained by the Alto Paraíso de Goiás Weather Station (INMET 2017), located about $70 \mathrm{~km}$ study area. The values of monthly precipitation were obtained locally using a rain gauge (pluviometer) installed in the Quilombola community Kalunga, about two thousand meters away from the study area (table 1).

The Variation Inflation Factor (VIF) was used to test the existence of multicollinearity among the predictive climatic variables. Finally, four variables with lower inflation values (VIF $\leq 3$ ) were selected to compose the set of predictor variables: total precipitation $(\mathrm{VIF}=2.17)$, maximum temperature
$(\mathrm{VIF}=3.07)$, relative humidity $(\mathrm{VIF}=2.49)$ and insolation ( VIF $=2.29$ ). This analysis performed in the R package faraway (Faraway 2016).

The Intensity index (II) of each phenophase was used to represent the response of the population to the climatic variables. Due to the high variability between the units of measurements of each variable, the entire data set was log-transformed $(\log +1)$. The effect of the predictive climatic variables on the emergence of new leaves, floral bud, flower and fruit was tested using multiple linear regression analysis using the $\mathrm{lm}$ function in the R package vegan (Oksanen et al. 2016).

\section{Results}

Abundance and density - We sampled 417 individuals of $A$. humile in the four sample plots, which resulted in an average density of 104.25 ind $\mathrm{ha}^{-1}( \pm 60.35$, $\mathrm{CV}=57.90 \%)$. The variability of the number of individuals registered between the plots was 46 to 189 (table 2).

The abundance of individuals in rocky outcrop soil (263) was greater than that found to individuals in without rock outcrops soil (154) (table 2). Plots with greater area with rocky outcrops presented a larger number of individuals on their outcrops $(\mathrm{A}=47.5851$; $\left.\mathrm{X}^{2}=21.0023 ; \mathrm{p}<0.0001\right)$, evidencing a preferential habitat for the species, since plots with greater proportion of areas without rock outcrops showed a decreasing trend in the number of individuals inventoried $\left(A=-47.5851 ; X^{2}=21.0023 ; p<0.0001\right)$. The disproportionality of the size of the area with rocky outcrops between the plots contributed to the high coefficient of variation of the average density of individuals inventoried (73\%) and contributed to the average density of individuals so that was not statistically different between the environments with and without rocky outcrops $(\mathrm{U}=5, \mathrm{p}=0.3865)$.

The density of branches per individual differed according to the environment in which it was found $(\mathrm{U}=17122, \mathrm{p}=0.0084)$. The medians of branches per tree were greater among those located in the sandy substrate without rocky outcrops ( 4.50 branches ind $^{-1}$ ) than those located within rocky outcrops ( 3 branches ind $\left.^{-1}\right)$.

Spatial Distribution - The spatial distribution pattern of the individuals found in the plots was aggregate, since the results of the Morisita's Index (Imor) were greater than the minimum value for a random distribution (Mclu), and the Standardized Morisita Index (Imst) was greater than 0.50 in all inventoried plots. The Chi- 
Table 1. Mean values of temperature, relative humidity $(\mathrm{RH})$, insolation and accumulated monthly precipitation in the study area, from May 2016 to April 2017.

\begin{tabular}{lcccccc}
\hline \multirow{2}{*}{ Month } & \multicolumn{3}{c}{ Temperature ${ }^{\circ} \mathrm{C}$} & RH (\%) & Precipitation & Insolation \\
\cline { 2 - 7 } & Maximum & Minimum & Mean & & $(\mathrm{mm})$ & $\left(\mathrm{Kj} \mathrm{m}^{-2}\right)$ \\
\hline 2016 & 21.83 & 20.17 & 20.98 & 62.35 & 0 & 775.23 \\
\hline May & 20.07 & 18.47 & 19.26 & 61.24 & 0 & 672.5 \\
June & 20.66 & 18.85 & 19.74 & 47.63 & 0 & 799.04 \\
July & 22.1 & 20.23 & 21.15 & 44.78 & 0 & 804.23 \\
Ago & 23.53 & 21.78 & 22.63 & 39.98 & 46 & 776.87 \\
Set & 22.94 & 21.41 & 22.15 & 44.85 & 43.7 & 798.96 \\
Oct & 22.16 & 20.78 & 21.45 & 56.01 & 267 & 767.02 \\
Nov & 21.87 & 20.44 & 21.14 & 59.1 & 210 & 849.41 \\
Dec & & & & & \\
\hline 2017 & 22.07 & 20.43 & 21.22 & 63.97 & 165 & 805.4 \\
\hline Jan & 20.89 & 19.72 & 20.27 & 69.86 & 240 & 655.16 \\
Feb & 21.81 & 20.31 & 21.03 & 68.06 & 203 & 783.92 \\
Mar & 21.66 & 20.25 & 20.94 & 72.57 & 125 & 755.03 \\
Apr & &
\end{tabular}

Table 2. Descriptive statistics of the number of individuals and branches of A. humile registered in four plots of cerrado stricto sensu area, in the Quilombola community Kalunga, Cavalcante, Goiás State, Brazil. Values followed by different letters presented significant differences $(\mathrm{p}<0.05)$.

\begin{tabular}{cccccc}
\hline & General & \multicolumn{2}{c}{ Without rocky outcrop soil } & \multicolumn{2}{c}{ Rocky outcrop soil } \\
\hline & Individuals & Individuals & Branches & Individuals & Branches \\
\hline Abundance & 417 & 154 & 904 & 263 & 1149 \\
Minimum & 46 & 27 & 1 & 19 & 1 \\
Maximum & 189 & 53 & 42 & 136 & 25 \\
Range Total & 143 & 26 & 41 & 117 & 24 \\
Median & 91 & $37 \mathrm{a}$ & $4,50 \mathrm{a}$ & $54 \mathrm{a}$ & $3 \mathrm{~b}$ \\
Mean & 104.25 & $38.5 \mathrm{a}$ & $5.87 \mathrm{a}$ & $65.75 \mathrm{a}$ & $4.37 \mathrm{~b}$ \\
Standard Dev. & 60.35 & 14.18 & 5.72 & 50.08 & 3.70 \\
Coefficient of variation & 57.90 & 31.63 & 97.48 & 76.17 & 84.84 \\
(\%) & & & & &
\end{tabular}

squared test results were significant (pchisq $<0.001$ ) in all plots (table 3 ).

One of the factors that contributed to the population aggregation was the size of the area with rocky outcrops within the plots. Sites with rocky outcrops showed greater abundance and density of individuals, and a spatially aggregated distribution pattern. By contrast, the sites without rocky outcrops presented more sparse individuals, including a random distribution pattern for plots 1 and 2 (table 4, figure 1).

Size structure - Individuals of the population of $A$. humile presented on average $87 \mathrm{~cm}( \pm 33.82)$ of total height, 4.92 branches $( \pm 4.60)$ and $0.97 \mathrm{~cm}( \pm 0.57)$ of basal diameter of the main branch. The data range for each parameter analyzed was large and the high standard deviation indicates a high dispersion of these data from the mean (table 5).

When analyzing the three variables together, it is noticeable that the total height data are more homogeneous than those of basal diameter and, especially, regarding the secondary branches, since its coefficient of variation $(\mathrm{CV})$ was the lower among them $(38.82 \%)$. On the other hand, the branch variable had a higher coefficient of variation $(93.56 \%)$, with specimens presenting from 1 to 42 branches (table 5).

Contrary to the observed for the medians of branch density per individuals, we did not find differences 
Table 3. Morisita's Indices values per plot and their spatial distribution patterns for individuals of Anacardium humile A. St.-Hil. inventoried in the Quilombola community Kalunga, Cavalcante, Goiás State, Brazil. Imor: Morisita's Index. Imst: Standardized Morisita's Index. Mclu: the upper limit of the Morisita's Index for a random distribution. Muni: the lower limit of the Morisita's Index for a random distribution. (**) Significant value at a level of $1 \%$.

\begin{tabular}{lccccc}
\hline Plot & Imor & Mclu & Muni & Imst & Pattern \\
\hline 1 & 2.20 & 1.28 & 0.81 & $0.53^{* *}$ & Aggregate \\
2 & 1.76 & 1.14 & 0.90 & $0.52_{* *}$ & Aggregate \\
3 & 1.40 & 1.07 & 0.95 & $0.51^{* *}$ & Aggregate \\
4 & 1.89 & 1.14 & 0.90 & $0.52^{* *}$ & Aggregate \\
\hline
\end{tabular}

Table 4. Morisita's Indices values in environments with and without rocky outcrops within each plot and respective spatial distribution pattern of individuals of Anacardium humile A. St.-Hil. inventoried in Quilombola community Kalunga, Cavalcante, Goiás State, Brazil. Imor: Morisita's Index. Imst: Standardized Morisita's Index. Mclu: the upper limit of the Morisita's Index for a random distribution. Muni: the lower limit of the Morisita's Index for a random distribution. $\left({ }^{*}\right)$ Significant value at a level of $5 \%$. (**) Significant value at a level of $1 \%$.

\begin{tabular}{lcccccccccc}
\hline \multirow{2}{*}{ Plot } & \multicolumn{4}{c}{ Without Rocky outcrops } & \multicolumn{5}{c}{ With Rocky outcrops } \\
\cline { 2 - 10 } & Imor & Mclu & Muni & Imst & Pattern & Imor & Mclu & Muni & Imst & Pattern \\
\hline 1 & 1.55 & 1.48 & 0.66 & $0.50^{*}$ & Random & 4.68 & 1.69 & 0.51 & $0.60^{* *}$ & Aggregate \\
2 & 1.25 & 1.43 & 0.70 & 0.29 & Random & 3.17 & 1.20 & 0.86 & $0.57^{* *}$ & Aggregate \\
3 & 3.10 & 1.24 & 0.83 & $0.56^{* *}$ & Aggregate & 1.80 & 1.09 & 0.93 & $0.52^{* *}$ & Aggregate \\
4 & 1.67 & 1.29 & 0.80 & $0.51^{* *}$ & Aggregate & 4.20 & 1.28 & 0.80 & $0.60^{* *}$ & Aggregate \\
\hline
\end{tabular}

Plot 1

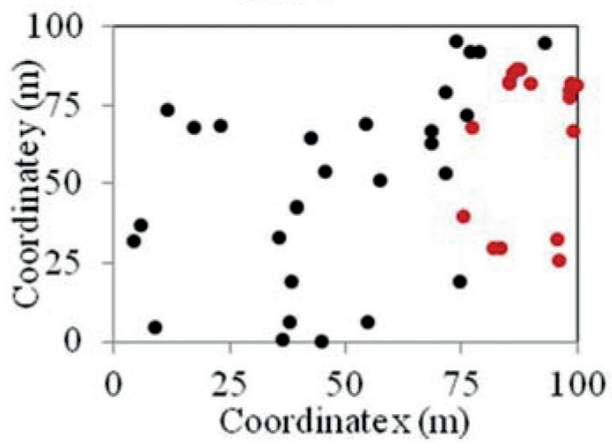

Plot 3

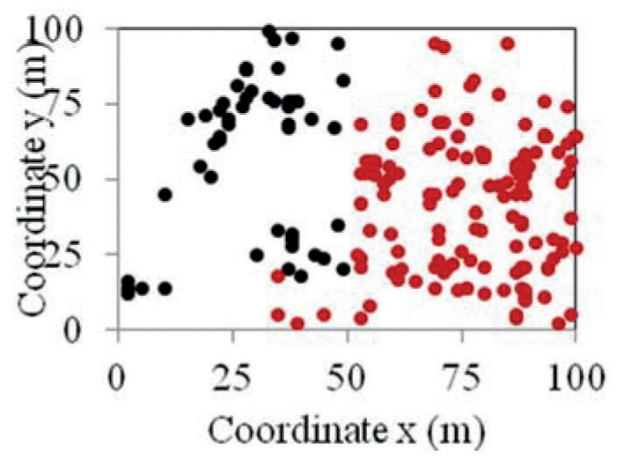

Plot 2

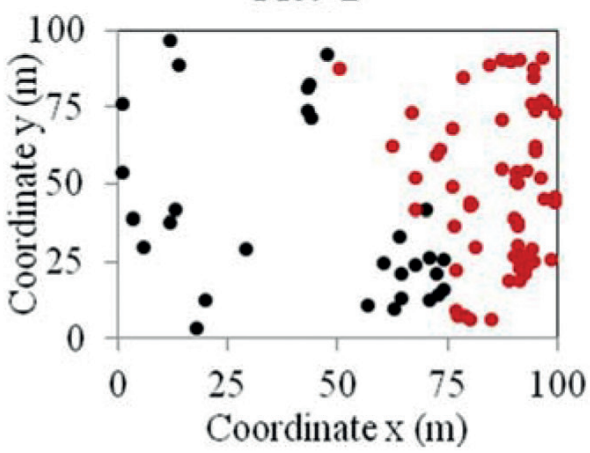

Plot 4

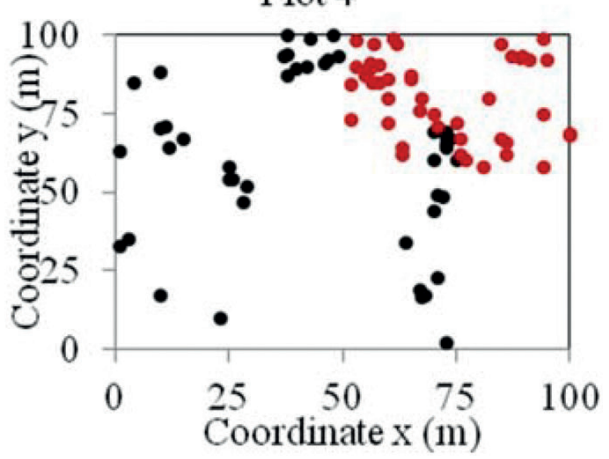

Figure 1. Spatial distribution of Anacardium humile A. St.-Hil. within four plots in the Quilombola community Kalunga, Cavalcante, Goiás State, Brazil. Distinct color scores represent specimens in different environments: without rock outcrop (black) and with rock outcrop (red). 
Table 5. Descriptive statistics of the parameters of total height, branches and basal diameter of the individuals of Anacardium humile A. St.-Hil. inventoried in the Quilombola community Kalunga, Cavalcante, Goiás State, Brazil.

\begin{tabular}{lccc}
\hline $\mathrm{n}$ (individuals) $=417$ & Total height $(\mathrm{cm})$ & Basal diameter $(\mathrm{cm})$ & Branch (unit) \\
\hline Minimum & 26 & 0.20 & 1.00 \\
Maximum & 260 & 7.20 & 42.00 \\
Range & 234 & 7.00 & 41.00 \\
Median & 80 & 0.90 & 3.00 \\
Mean & 87 & 0.97 & 4.92 \\
Standard Deviation & 33.82 & 0.57 & 4.60 \\
Coefficient of variation (\%) & 38.83 & 58.27 & 93.56 \\
\hline
\end{tabular}

between the medians of height $(\mathrm{U}=19080, \mathrm{p}=0.3242)$ and basal diameter $(\mathrm{U}=19984.5, \mathrm{p}=0.8225)$ of the individuals located in environments with and without rocky outcrops. Thus, regardless of the environment in which they are within the plot, the individuals have the same size. The number of branches and the total height of $A$. humile individuals presented low correlation $(\mathrm{rho}=0.36, \mathrm{p}<0.001)$.

Most individuals (53\%) had between $0.20 \mathrm{~cm}$ and 0.93 $\mathrm{cm}$ of basal diameter - with a decrease of individuals in the classes above $1.66 \mathrm{~cm}$ (figure 2) - and height ranging from $50-122 \mathrm{~cm}$ (figure 3). We did not find individuals with $\mathrm{BD}<0.20 \mathrm{~cm}$ and total height less than $0.26 \mathrm{~m}$, in the ontogenetic stage of seedlings.

The studied population presented greater investment in height than in basal diameter since the allometric coefficient of the linear regression between basal diameter and total height $(\mathrm{F}=$ 402.464, $\mathrm{p}<0.0001, \mathrm{R} 2=0.4923$ ) was higher than $1(b=1.1817)$ (figure 4). Moreover, there are differences in the height / diameter ratio according to diametric classes $(H=821424, p<0.001)$. We noticed a decreasing in this ratio as individuals increase in diameter. The height investment is greater between $0.20-0.93 \mathrm{~cm}$ of diameter and becomes smaller in the following classes, especially from $1.66 \mathrm{~cm}$ (figure 5).

Phenology - All monitored plants maintained their leaves throughout the year (evergreen) and only two plants showed no reproductive phenophases. Changes in the phenophases occurred mainly from May to September 2016. The emergence of new leaves occurred between May to November 2016 and from February 2017. The peak of synchronization (AI) of this phenomenon occurred in August 2016, although it was more intense (II) in the months of June - right after the plants started the reproductive period - and in August, with the decrease in the number of plants with flower bud emergence.
The floral bud emergence occurred from May to September, with a higher frequency between May and August, presenting higher AI and II in July. Flowering also occurred between May and September, with a peak in the activity and intensity of the phenophase in July, and in a smaller quantity in August. Fruiting occurred between July and September, with higher AI and II in August (figure 6 and figure 7).

According to the regression models, precipitation explained $68 \%$ of the variation in the emergence of new leaves (leaf out), with greater occurrence of this phenophase in the months of lower precipitation $(\beta=-0.41)$. The maximum temperature $(\beta=-26.96)$, relative humidity $(\beta=-4.84)$ and precipitation $(\beta=-0.22, p=0.05)$ corresponded, inversely proportional, for $87 \%$ of the causes that induced the floral bud emergence by plants. The variables maximum temperature $(\beta=-26.55)$ and relative humidity $(\beta=-5.83)$ explained $75 \%$ of flowering, which was more intense during the months that presented lower maximum temperatures and lower relative humidity. Yet for fruit production phenomena, there were no climatic variables with significant beta values. It was only observed an influence of relative humidity $(\beta=-6.24, \mathrm{P}=0.06)$, inversely proportional, on the intensity of this phenophase (table 6).

\section{Discussion}

The occurrence of sites with rocky outcrops, where the species showed the greatest abundance, explains the high variation in density of individuals within the study area. Plots with higher occurrence of rocky outcrops showed higher abundance of $A$. humile, demonstrating the affinity of the species with this type of environment. Sites with rocky outcrops have few and small spaces for plants, shallow soils with low water storage capacity, subject to long periods of water shortage and short moments with excessive 


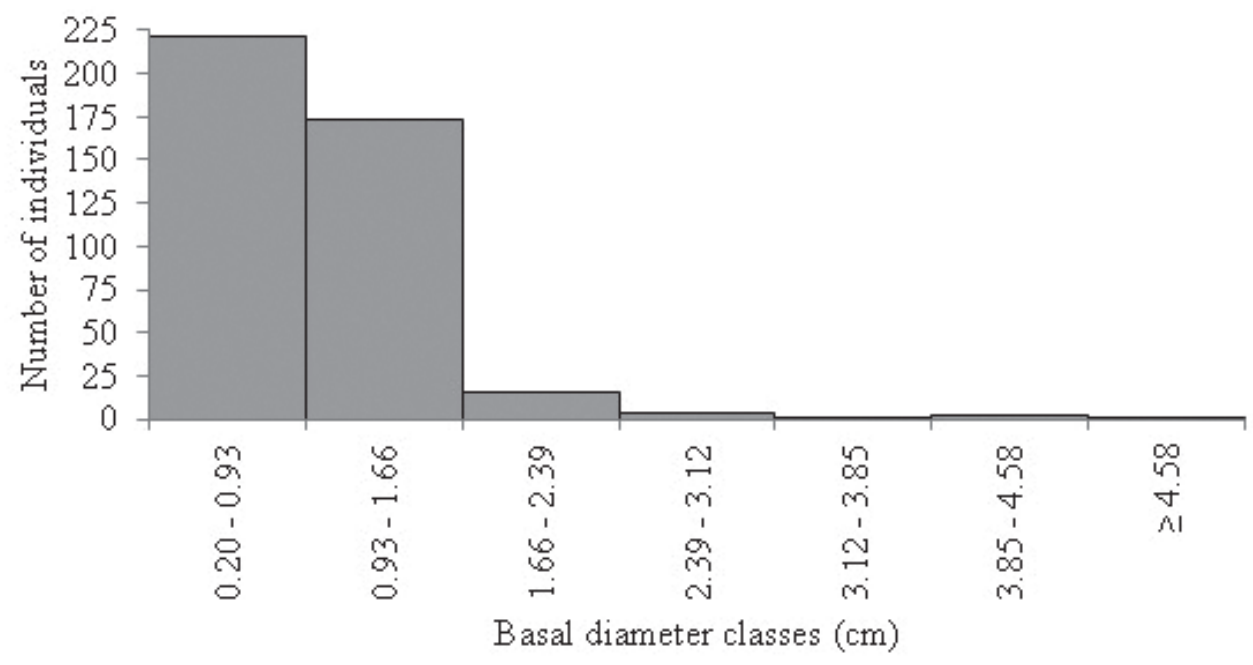

Figure 2. Distribution of individuals of the population of Anacardium humile A. St.-Hil. in classes of basal diameter (cm), inventoried in the Quilombola community Kalunga, Cavalcante, Goiás State, Brazil.

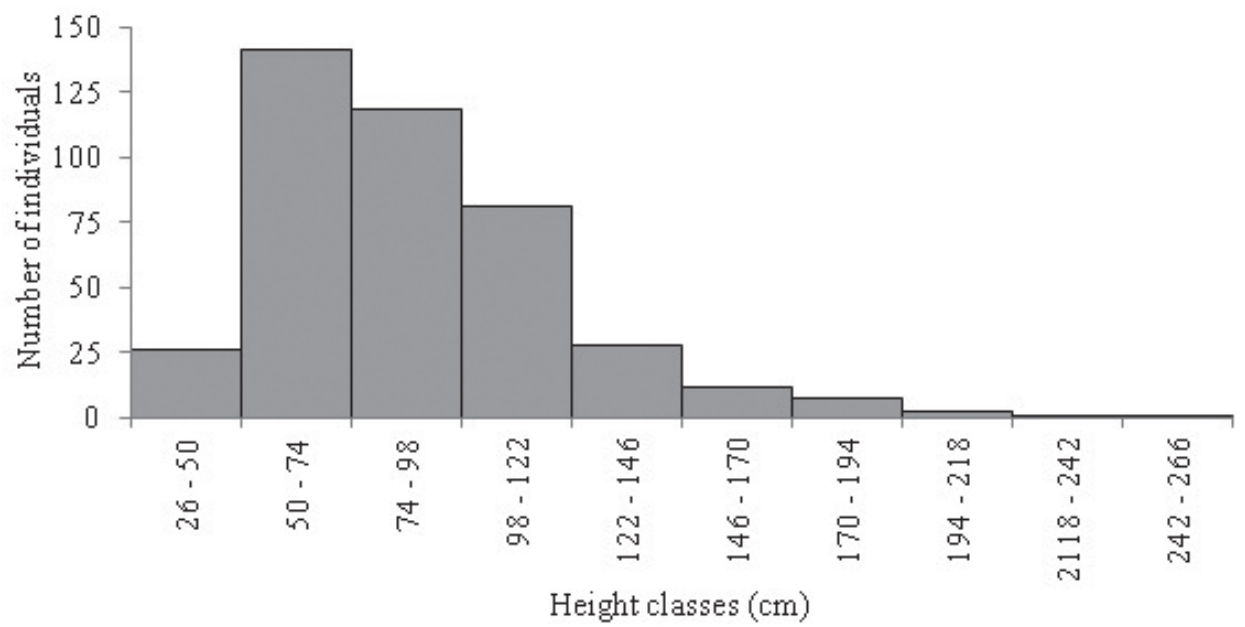

Figure 3. Distribution of individuals of the population of Anacardium humile A. St.-Hil. in classes of total height (cm), inventoried in the Quilombola community Kalunga, Cavalcante, Goiás State, Brazil.

water and floods, as well as the punctual accumulation of organic matter, great daily temperature range and high insolation (Harley 1995, Conceição \& Giulietti 2002, Conceição \& Pirani 2005, Conceição 2006).

An important factor that may be contributing to the greater abundance of the species is the heterogeneity of the fire distribution in the areas of rocky outcrop. The absence or low amount of fuel in the exposed rock prevents the continuity of the fire and contributes to the formation of a mosaic of burned areas, remaining islands of vegetation not affected directly by the fire (Conceição \& Pirani 2005, Neves \& Conceição 2010). These environments can be called nurse rocks, since they facilitate the reestablishment of plants after the passage of fire (Gonçalves et al. 2016), especially when compared to sandy soils with no outcrops (Brito 2011).

The fire history and the greater space available for the development and growth of vegetative structures in sandy soil without rocky outcrops may explain the higher density of branches per individual than those located in rocky outcrops. The plants located in places without rocky outcrops may have suffered greater damage due to the fire that occurred five years ago, and those that survived produced, in response, a increased number of regrowth. On the other hand, the individuals that were in the rocky outcrops, more protected from the fires, possibly had fewer injuries 


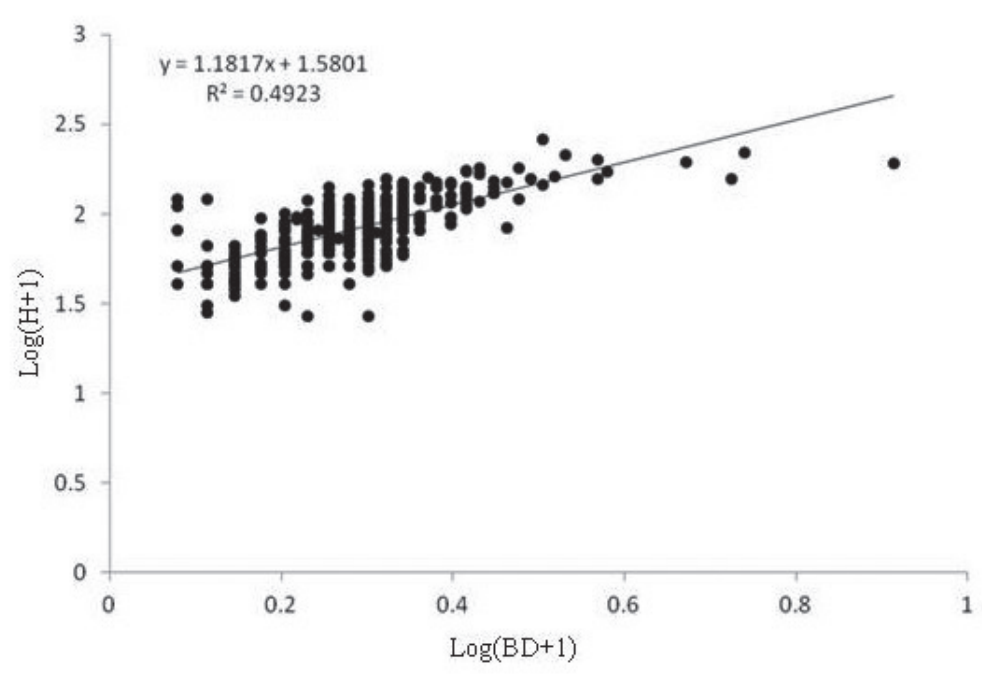

Figure 4. Regression line and correlation between basal diameter $(\mathrm{BD})$ and total height $(\mathrm{H})$ data of a population of Anacardium humile A. St.-Hil. inventoried in the Quilombola community Kalunga, Cavalcante, Goiás State, Brazil.

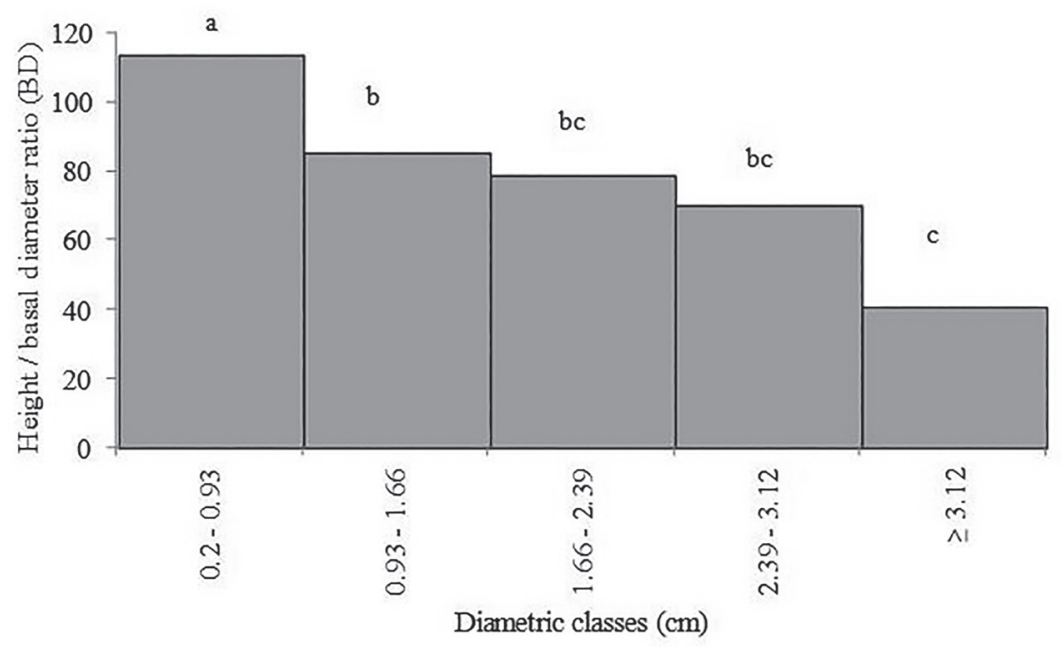

Figure 5. Height / basal diameter ratio (BD) in Anacardium humile A. St.-Hil. plants in different diametric classes, inventoried in the Quilombola community Kalunga, Cavalcante, Goiás State, Brazil. Means followed by the same letters do not differ statistically from each other at $5 \%$ probability by the SNK test.

and lower mortality rates, that resulted in the lower stimulus of regrowth, and were still influenced by the spatial and edaphic limitation for their development.

The aggregate spatial distribution pattern of the individuals seems to be predominant among the arboreal-shrub species of the Cerrado (Bernasol \& Lima-Ribeiro 2010). Aggregation is common in tropical species with asexual propagation (LimaRibeiro \& Prado 200, Pare et al. 2009), capacity observed in $A$. humile, but can also be caused by local seed dispersal events (Hubbel 1979, Nathan \& Muller-Landau 2000) and due to environmental heterogeneity (Barbour et al. 1987, Hutchings 1997, Thomas \& Kunin 1999, Hardy \& Sonké 2004).

It is evident the performance of the rocky outcrops environmental heterogeneity - as a strong mechanism acting in the demographic arrangement of $A$. humile. For Hutchings (1997), different soil patches with suitable conditions for the establishment of the individuals and dispersal agents in an area, and the greater adaptability of the population causes aggregation due to the local environmental variations. Moreover, the vegetative propagation capacity of the species also influences the growth of branches parallel 


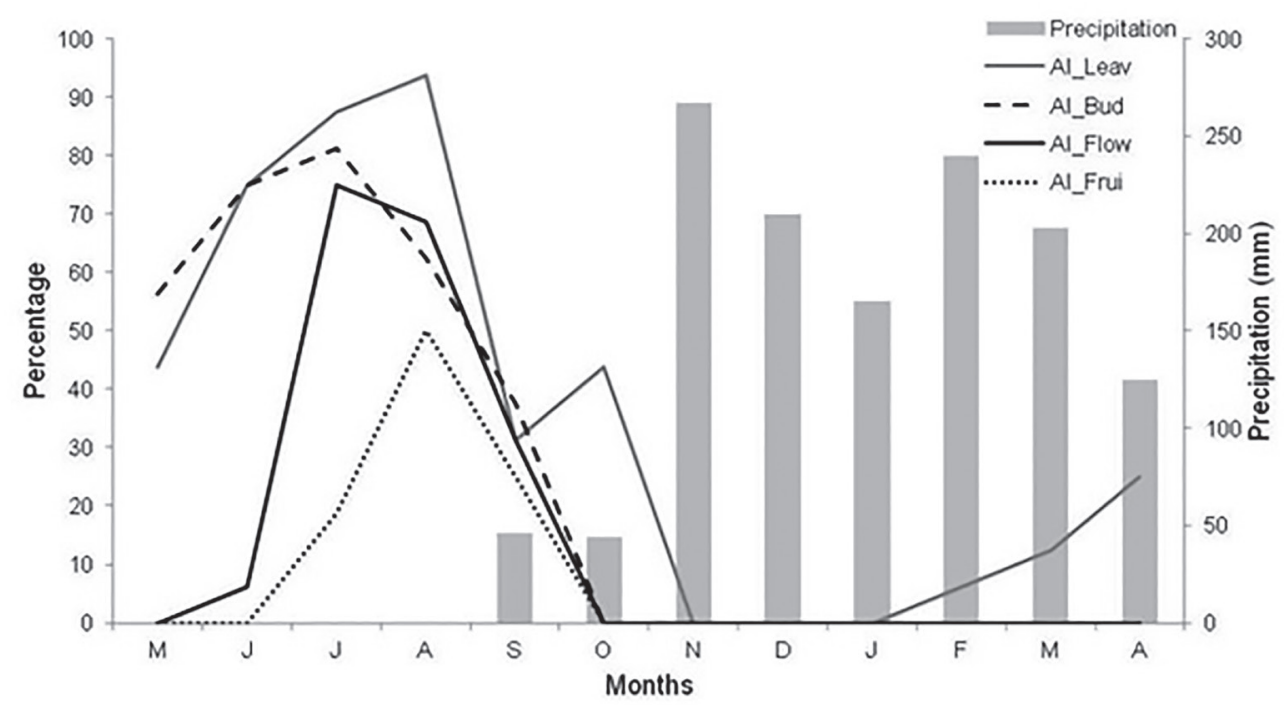

Figure 6. Phenogram built with phenological data of the Activity Index (AI) for the phenophase of new leaves emergence (AI Leav), floral bud emergence (AI_Bud), production of flowers (AI_Flow) and fruits (AI_Frui) of Anacardium humile A. St.-Hil., in a Cerrado stricto sensu area in the Quilombola community Kalunga, Cavalcante, Goiás State, Brazil.

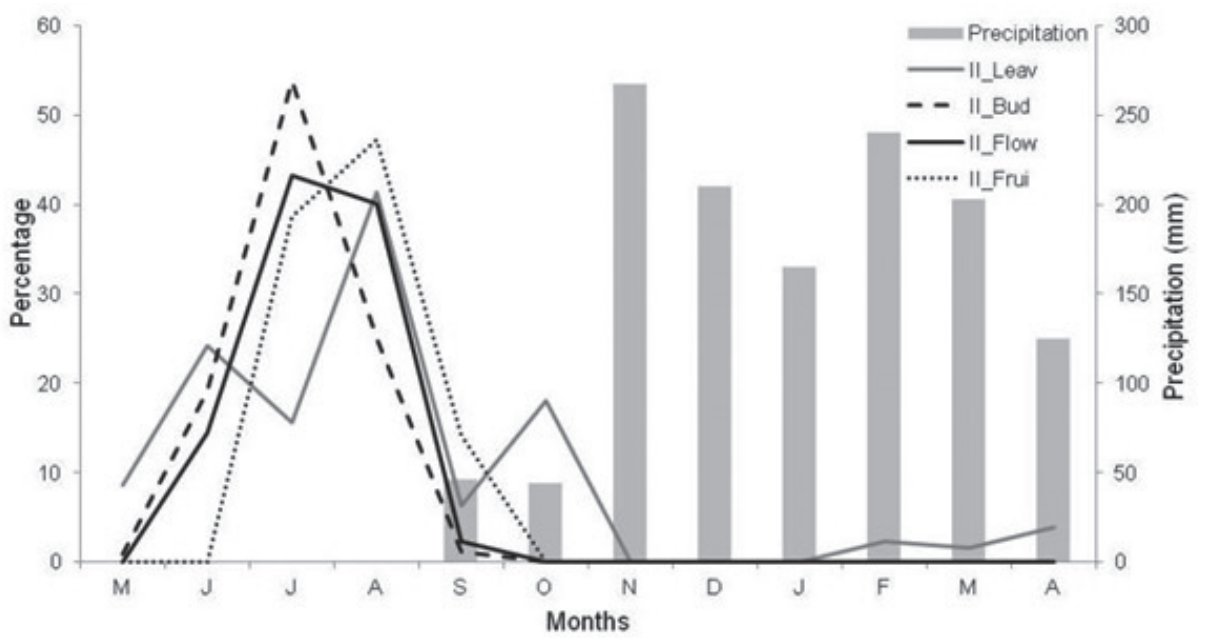

Figure 7: Phenogram built with phenological data of the Intensity Index (II) for emergence of new leaves (II_Leav), floral buds (II_Bud), production of flowers (II_Flow) and fruits (II_Frui) of Anacardium humile A. St.-Hil., in a Cerrado stricto sensu area in the Quilombola community Kalunga, Cavalcante, Goiás State, Brazil.

to the soil. Grando (2009) found this same distribution pattern for the branches of another population of $A$. humile.

We found great variation in total height, basal diameter, and number of branches per individuals within the study population, indicating the high morphological variability of the species. The distributions in diameter and height classes presented higher numbers of individuals in the lower classes, typical of populations with a stable size structure. The pattern found, also called inverted-J, shows the species' performance against stochastic events, competition for nutrients, light and water, as well as herbivores attack, pathogens, physical damages and density-dependent factors, especially in the early stages of life (Janzen 1970, Augspurger 1983, Harper 1990).

In the present study, this pattern is not only a result of successful recruitment of sexually conceived individuals (genets). The small number of individuals in the class of $0-50 \mathrm{~cm}$ high indicates a low amount of inventoried regenerants (seedlings and infants) and the causes for this may be related to the post-seed dispersal time in which this census was 
Table 6. Results of multiple regression analyzes between climatic variables and phenological parameters of new leaves emergence (Pheno leav), floral bud (Pheno bud), flowering (Pheno flow) and fruiting (Pheno Frui) in plants of Anacardium humile A. St.-Hil. registered in the Quilombola community Kalunga, Cavalcante, Goiás State, Brazil. Max.Temp.: maximum temperature. RH: relative humidity.

\begin{tabular}{ccccccc}
\hline Response variable & $\mathrm{r}_{\mathrm{a}}{ }^{2}$ & $\mathrm{~F}$ & $\mathrm{p}$ & $\begin{array}{c}\text { Explanatory } \\
\text { variable }\end{array}$ & $\begin{array}{c}\text { Angular } \\
\text { coefficient }(\beta)\end{array}$ & $\mathrm{p}$ \\
\hline Pheno_leav & 0.68 & 6.86 & 0.01 & Precipitation & -0.41 & 0.01 \\
Pheno_bud & 0.87 & 19.48 & $<0.01$ & Max. Temp. & -26.96 & $<0.01$ \\
& & & & RH & -4.84 & $<0.01$ \\
& & & & Precipitation & -0.22 & 0.05 \\
Pheno_flow & 0.75 & 9.39 & $<0.01$ & Max. Temp. & -26.55 & 0.03 \\
& & & & RH & -5.83 & 0.01 \\
Pheno_frui & 0.65 & 3.27 & 0.08 & RH & -6.24 & 0.06 \\
\hline
\end{tabular}

conducted (more than seven months after the fruiting occurred in 2015) and the responses of development, growth, and establishment in the environment by the specimens, as well as the species difficulty to form sub-population, as observed by Faria et al. (2013) for Brosimum gaudichaudii Trécul in the Cerrado area, state of Mato Grosso. Moreover, the low frequency of individuals in this class may also show a more recent recruitment, perhaps due to the origin of the post-fire event, considering that this area suffered forest fire five years ago.

In fact, vegetative reproduction or branching in response to events such as fires, common in the Cerrado woody plants (Coutinho 1990, Ramos 1990, Muramaki \& Klink 1996, Rocha \& Silva 1999, Hoffmann \& Solbrig 2003, Sato 2003) can explain the large number of individuals in the smaller size classes. There is a large literature that presents rapid post-fire recovery, through sprouts in the epigeal part from the gemmiparous roots or from the basal portion of the stem (Miranda \& Sato 2005).

The total height of the specimen was not influenced by the number of branches per individuals, which suggests low competition for light between them. This result contradicted our hypothesis that the greater the number of branches in an individual, the greater would be their total height, due to competition for light and space. However, the most significant investment in height, especially in the first diametric classes, found for A. humile, shows that individuals are taller than thick and their branches, although flexible and with a small diameter, are sufficient to support the aerial part. Moreover, this behavior is attributed by Dodonov et al. (2011), after analyzing the allometry of Dalbergia miscolobium Benth.,
Diospyros hispida A. DC., Miconia ligustroides (DC.) Naudin, Schefflera vinosa (Cham \& Schltdl.) Frodin \& Fiaschi and Xylopia aromatica (Lam.) Mart., as a response of many species to recurrent fires in the Cerrado. Fernandes (2012) evaluated survival and initial growth after fire disturbance of Anacardium humile A. St.-Hil., Dipteryx alata Vogel, Magonia pubescens A. St.-Hil. and Tabebuia aurea (Silva Manso) Benth. \& Hook.f. ex S.Moore, and found high growth rates and number of leaves for A. humile, which reported the greatest response to the fire effect.

It is likely that the fire occurred in the study area five years ago has profoundly altered the structure of the $A$. humile population through the massive topkill effect and subsequent resprouts of individuals. This explains why $53 \%$ of the individuals were in the first class of basal diameter and $41 \%$ in the second class. Other studies also showed changes in the population structure after fire events, such as greater number of sprouts (branches) and changes in height and diameter of plants as in Kielmeyera coriacea Mart. \& Zucc. and Stryphnodendron adstringens (Mart.) Coville (Neto et al. 2008), Kielmeyra coriacea Mart. and Zucc., Kielmeyera grandiflora (Wawra) Saddi, Tabebuia aurea (Silva Manso) Benth. \& Hook.f. ex S. Moore and Ouratea hexasperma (A. St.-Hil.) Baill (Vale \& Lopes 2010). According to them, the plants suffered damages mainly in the layers below $1.5 \mathrm{~m}$, leading to the death of the aerial part ("topkill") in most of them, and later emergence of underground and aerial sprouts, modifying the populations. Among the species, $K$. grandiflora was stood out for its rapid growth from the underground structures.

The evergreen pattern found for A. humile is common for Cerrado plants (Oliveira 1991). The 
emergence of new leaves was intense in two periods both among the months of least precipitation - related to the emergence of floral buds and flowers: one that precedes the peak in intensity of floral bud and flower emergence at the beginning of the dry period, and right after the cessation of these emissions, in the midst of the rainy period. Thus, after the emergence of new leaves, the plant emits the inflorescence in the same branch. The investment in the emergence of new leaves is only resumed after the cessation of floral bud's emergence. In this case, the presence of new leaves is likely to increase the energy efficiency of the plants, providing the energy needed for the subsequent flowering and fruiting peak, as observed by Pirani et al. (2009) in the State of Mato Grosso.

The strategy of sprouting and leaf development before or at the beginning of the rainy season is common in perennial savanna plants (Montes \& Medina 1977, Sarmiento et al. 1985, Felfili et al. 1999, Lenza \& Klink 2006, Oliveira 2008, Silvério \& Lenza 2010, Faria et al. 2015). This contributes to the development of their more efficient photosynthetic, in addition to greater resistance to insect predation attacks during the rainy season (Lieberman 1982, Felfili et al. 1999, Silvério \& Lenza 2010). The presence of tubers, as in A. humile, is one of the adaptations of Cerrado plants to water shortage (Jackson et al. 1999, Franco et al. 2005, Faria et al. 2015), which allows the production of leaves in dry period and maintenance of the foliage throughout the year (Sarmiento et al. 1985, Felfili et al. 1999, Franco et al. 2005, Lenza \& Klink 2006, Oliveira 2008, Soares et al. 2014, Faria et al. 2015).

Phenophases of floral bud emergence and flowering were negatively influenced by maximum temperature, relative humidity, and precipitation. Flowering during drought seems to be a common pattern of the Cerrado tree vegetation (Miranda 1995, Gouveia \& Felfili 1998, Batalha \& Mantovani 2000, Lenza \& Klink 2006, Tannus et al. 2006, Pirani et al. 2009), and also of other tropical forests (Janzen 1980, Murali \& Sukumar 1994, Justiniano \& Fredericksen 2000). The highest intensity of flower bud and flower emergence found in this study occurred when the maximum temperatures were lower. These changes in temperatures, together with the reduction of the photoperiod in the dry season, are considered variables that induce flowering (Fournier 1966, Janzen 1967, Araújo 1970, Daubenmire 1972, Lieberman 1982, Silvério \& Lenza 2010). Flower production occurred in the period of least precipitation and according to Janzen (1967), this is a strategy of savanna species to avoid damage to their flowers during rainfall. Moreover, according to this author, the flowers are easier to be discovered and pollinated, thanks to the deciduous plant communities, besides benefiting from the reduction of herbivory in this period.

The fruit production had a peak of intensity in August, suggesting seed dispersal right before the onset of rains. This increases the probability of seedling germination and growth, when the seeds are benefited by the moisture and abundance of nutrients released from the decomposition of the accumulated litter in the dry season and propitiates the development of a deep root system before the next drought (Felfili et al. 1999, Oliveira 2008, Pirani et al. 2009, Silvério \& Lenza 2010). In this case, A. humile has its reproductive phenology directed to ripen fruits and release seeds at periods more suitable to the growth and survival of their seedlings. The fact that the seeds of this species do not present dormancy (Avila et al. 2009) and use seedling establishment as a survival strategy (Carvalho et al. 2005) reinforce the present hypothesis.

Although Anacardium humile has been found in the cerrado stricto sensu and campo sujo areas, the few studies carried out with this species show a lack of knowledge on its distribution in the Cerrado and its phytophysiognomies. This work demonstrated that in cerrado stricto sensu, individuals are distributed in an aggregate form and that rocky outcrops can enhance this pattern. The specimens present great range in diameter, height, and number of branches, being able to emerge new branches after the occurrence of events such as fires. The vegetative and reproductive phenologies of the species present significant changes in the dry period, as a strategy for the dispersion of seeds and subsequent establishment of the plants during the beginning of the rainy period. In this way, this study shows important results on the population ecology that can contribute in the development of management plans for the conservation of the species.

\section{Acknowledgments}

D.G.S thanks IBAMA for the license granted to attend the undergraduate program RENAC/UEG, to FAPEG for the scholarship no 201610267000635 , awarded during the Master's and to the Brigada Kalunga de Prevenção e Combate aos Incêndios Florestais (IBAMA/PREVFOGO) for supporting the field study. H.F.C thanks CNPq for the CNPq research productivity fellowships (Process n. 302198/2015-6). 


\section{Literature cited}

Aidar, M.P.M. 1992. Ecologia do Araribá (Centrobium tomentosum Guill. Ex Benth.- Fabaceae) e o ecótopo Mata Ciliar da Bacia do Rio de Jacaré-pepira. Dissertação de Mestrado, Universidade de Campinas, Campinas.

Almeida, S.P., Proença, C.E.B., Sano, S.M., Ribeiro, J.F. 1998. Cerrado: espécies vegetais úteis. EMBRAPACPAC, Planaltina.

Araújo, G.M., Fransciscon, C.H., Nunes, J.G. 1987. Fenologia de nove espécies arbóreas de um cerrado no município de Uberlândia-MG. Revista do Centro de Ciências Biomédicas da Universidade Federal de Uberlândia 3: 3-17.

Araújo, V.C. 1970. Fenologia de essências florestais amazônicas. Boletim de Pesquisas Florestais do Instituto Nacional de Pesquisas da Amazônia 4: 1-25.

Arrigoni-Blank, M.F., Carvalho, D.A., Blank, A.F., Alvarenga, A.A., Vilela, E.A. 1996. Comportamento fenológico da casaqueira (Campomanesia rufa (Berg.) Nied.) durante o período de 1991-1992. Ciência e Agrotecnologia 20: 352-356.

Augspurger, C.K. 1983. Seed dispersal of the tropical tree Platypodium eleagans, and the escape of its seedlings from fungal pathogens. Journal of Ecology 71: 759-771.

Ávila, M.A., Santos, P.F., Braga, L.L., Rodrigues, P.L., Veloso, M.D.M., Nunes, Y.R.F., Fernandes, G.W. 2009. Biometria e Germinação de frutos de Anacardium humile A. St.-Hil. (Anacardiaceae) provenientes da APA Pandeiros, Minas Gerais. In: Anais do $9^{\circ}$ Congresso de Ecologia do Brasil, São Lourenço, pp. 1-3.

Ayres, M., Ayres Júnior, M., Ayres, D.L., Santos, A.A. 2007. BIOESTAT - Aplicações estatísticas nas áreas das ciências bio-médicas. Instituto Mamirauá, Belém.

Barbour, M.G., Burk, J.H., Pitts, W.D. 1987. Terrestrial Plant Ecology. 2 ed. Benjamim/Cummings, California.

Barroso, G.M., Morim, M.P., Peixoto, A.L., Ichaso, C.L.F. 1999. Frutos e sementes: morfologia aplicada à sistemática de dicotiledôneas. Editora UFV, Viçosa.

Batalha, M.A. \& Mantovani, W. 2000. Reproductive phenological patterns of cerrado plant species at the Pe-de-Gigante Reserve (Santa Rita do Passa Quatro, SP, Brazil): a comparison between the herbaceous and woody floras. Revista Brasileira de Biologia 60: 129-145.

Benker, C.S.C., Morellato, L.P.C. 2002. Comparação de dois métodos de avaliação da fenologia de plantas, sua interpretação e representação. Revista Brasileira de Botânica 25: 269-275.

Berg, E. 2001. Estrutura e ecologia de comunidades e populações vegetais. Textos Acadêmicos. UFLA/ FAEPE, Lavras.

Bernasol, W.P. \& Lima-Ribeiro, M.S. 2010. Estrutura espacial e diamétrica de espécies arbóreas e seus condicionantes em um fragmento de cerrado stricto sensu no sudoeste goiano. Hoehnea 37: 181-198.
Brito, J.C. 2011. Efeitos do fogo sobre a vegetação em duas áreas de campo rupestre na Chapada Diamantina, Bahia, Brasil. Dissertação de Mestrado, Universidade Estadual de Feira de Santana, Feira de Santana.

Bruzinga, J.S., Oliveira, M.L.R., Machado, E.L.M., Leite, H.G., Pereira, I.M., Nogueira, G.S. 2013. Distribuição espacial de individuos adultos de pequi. Scientia Forestalis 41: 249-256.

Budke, J.C., Giehl E.L.H., Athayde E.A., Záchia R.A. 2004. Distribuição espacial de Mesadenella cuspidata (Lindl.) Garay (Orchidaceae) em uma floresta ribeirinha em Santa Maria, RS, Brasil. Acta Botanica Brasilica 18: 31-35.

Carvalho, M.P., Santana, D.G., Ranal, M.A. 2005. Emergência de plântulas de Anacardium humile A. St.-Hil. (Anacardiaceae) avaliada por meio de amostras pequenas. Brazilian Journal of Botany 28: 627-633.

Conceição, A.A. 2006. Plant ecology in 'campos rupestres' of the Chapada Diamantina, Bahia. In: L.P. Queiroz, A. Rapini \& A.M. Giulietti (eds.). Towards greater knowledge of the brazilian semi-arid biodiversity. Ministério da Ciência e Tecnologia, Brasília, pp 63-67.

Conceição, A.A. \& Giulietti, A.M. 2002. Composição florística e aspectos estruturais de campo rupestre em dois platôs do Morro do Pai Inácio, Chapada Diamantina, Bahia, Brasil. Hoehnea 29: 37-48.

Conceição,A.A. \& Pirani, J.R. 2005. Delimitação de habitats em campos rupestres na Chapada Diamantina: substratos, composição florística e aspectos estruturais. Boletim de Botânica da Universidade de São Paulo 23: 85-111.

Costa, C.R. 2006. Distribuição espacial e relações alométricas de espécies de Vochysiaceae em fragmentos de cerrado no município de Itirapina, São Paulo. Dissertação de Mestrado, Universidade Estadual de Campinas, Campinas.

Coutinho, L.M. 1990. Fire in the Ecology of Brazilian Cerrado. In: J. G. Goldammer (ed.). Fire in the tropical biota: Ecological processes and global challenges. Springer-Verlag, Berlin, pp. 82-105.

Dale, M.R.T. 1999. Spatial pattern analysis in plant ecology. Cambridge University Press, Cambridge.

Dalponte, J. C. \& Lima, E. D. S. 1999. Disponibilidade de frutos e a dieta de Lycalopex vetulus (CarnivoraCanidae) em um cerrado de Mato Grosso, Brasil. Revista Brasileira de Botânica 22: 325-332.

Daubenmire, R. 1972. Phenology and other characteristics of tropical semi-deciduous forest in Norht-Western Costa Rica. Journal of Ecology 60: 147-170.

Dodonov, P., Lucena, I.C., Leite, M.B., Silva-Matos, D.M. 2011. Allometry of some woody plant species in Brazilian savanna after two years of a dry season fire. Brazilian Journal of Biology 71: 527-535.

Elias, F., Marimon, B. S., de Almeida Reis, S. M., Forsthofer, M., Gomes, L., Morandi, P. S., MarimoJunior, B. H. 2013. Dinâmica da distribuição espacial de populações arbóreas, ao longo de uma década, em cerradão na transição Cerrado-Amazônia, Mato Grosso. Biota Amazônia 3: 1-14. 
EMBRAPA - Empresa Brasileira de Pesquisa Agropecuária. 2006. Sistema Brasileiro de Classificação de Solos. 2 ed. Embrapa Solos, Rio de Janeiro.

Epperson, B.K. 1989. Spatial patterns of genetic variation within plant populations. In: A.H.D. Brown, M.T. Clegg, A.L. Kahler, B.S. Weir (eds.). Plant Population Genetics, breeding and genetic resource. Sinauer Associates, Massachusetts pp. 229-253.

Faraway, J. 2016. Faraway: Functions and Databases for Books by Julian Faraway. Available in https://CRAN.Rproject.org/ package=faraway (accesso in 10-III-2017).

Faria, R.A.P.G., Coelho, M.F.B., Albuquerque, M.C.F, Azevedo, R.A.B. 2013. Distribuição espacial e estrutura populacional de Brosimum gaudichaudii Trécul. no cerrado de Mato Grosso, Brasil. Enciclopédia Biosfera, Centro Científico Conhecer 9: 3386-3395.

Faria, R.A.P.G., Coelho, M.F.B., Albuquerque, M.C.F, Azevedo, R.A.B.. 2015. Fenologia de Brosimum gaudichaudii trécul. (Moraceae) no cerrado de Mato Grosso. Ciência Florestal 25: 67-75.

Felfili, J.M., Silva-Junior, M.C., Dias, B.J., Rezende, A.V. 1999. Estudo fenologico de Stryphnodendron adstringens (Mart.) Coville no cerrado sensu stricto da Fazenda Agua Limpa no Distrito Federal, Brasil. Revista Brasileira de Botânica 22: 83-90.

Fernandes, T.A. 2012. Sobrevivência e crescimento inicial de espécies de cerrado após perturbação por fogo. Dissertação de Mestrado, Universidade Federal do Tocantins, Porto Nacional.

Ferrão, J.E.M. 1995. O cajueiro (Anacardium occidentale L.). Instituto de Investigação Cientifica Tropical, Lisboa.

Fidelis, A., Müller, S.C., Pillar, V.D., Pfadenhauer, J. 2007. Efeito do fogo na ecologia de populações de herbáceas e arbustos dos Campos Sulinos. Revista Brasileira de Biociências 5: 303-305.

Fournier, L.A. 1974. Un método cuantitativo para La medición de características fenológicas en árbores. Turrialba 24: 422-423.

Fournier, L.A. 1976. El dendrofenograma, una representación gráfica del comportamiento de los árbores. Turrialba 26: 96-97.

Fournier, L.A. 1966. Algunas observaciones sobre la dinâmica de la floracion en el bosque húmedo de Villa Cólon. Revista de Biologia Tropical 14: 75-85.

Franco, A.C., Bustamante, M.M., Caldas, L.S., Goldstein, G., Meinzer, F.C., Kozovits, A.R., Rundel, P., Coradin, V.T.R. 2005. Leaf functional traits of Neotropical savanna trees in relation to seasonal water deficit. Trees Structure and Function 19: 326-335.

França, D. P. F., Freitas, M. A., Ramalho, W. P. \& Bernade, P. S. 2017. Diversidade local e influência da sazonalidade sobre taxocenoses de anfíbios e répteis na Reserva Extrativista Chico Mendes, Acre, Brasil. Iheringia Série Zoologia 107: 1-12.
Frankham, R., Ballou, J.D., Briscoe, D.A. 2008. Fundamentos de genética da conservação. Sociedade Brasileira de Genética, Ribeirão Preto.

Fundação Grupo Boticário. 2011. Plano de Manejo da Reserva Natural Serra do Tombador. Supervisor: G. A. Gatti. Curitiba, Brasil. Available in http://www. fundacaogrupoboticario.org.br (access in 28-V-2017).

Garcia, F.N., Ferreira, L.G., Leite, J.F. 2011. Áreas Protegidas no Bioma Cerrado: fragmentos vegetacionais sob forte pressão. In: Anais do XV Simpósio Brasileiro de Sensoriamento Remoto, INPE, Curitiba, pp. 4086-4093.

Gonçalves, B., Carneiro, V.A., Bernardo, P.V.S., Paula, V.R., Silva-Neto, C.M. 2016. Aula biogeográfica sobre rochas enfermeiras: facilitação no (re) estabelecimento de plantas em cerrado rupestre no Parque Estadual da Serra de Caldas Novas - GO. Presença Geográfica 3: 45-53.

Gouveia, G.P. \& Felfili, J.M. 1998. Fenologia de comunidades de cerrado e de mata de galeria no Brasil Central. Revista Árvore 22: 443-450.

Grando, C. 2009. Aspectos da demografia do cajueirodo- campo (Anacardium humile) em áreas de Cerrado do Estado de São Paulo e construção de bibliotecas enriquecidas de microssatélites para a espécie. Dissertação Mestrado, Escola Superior de Agricultura Luiz de Queiroz, Piracicaba.

Gurevitch, J., Scheiner, S.M., Fox, G.A. 2009. Ecologia Vegetal. 2 ed. Artmed Editora, Porto Alegre.

Hairston, N.G., Hill, R., Ritte, U. 1971. The interpretation of aggregation patterns. In: G.P. Patil, E.C. Pileou, W.E. Waters (eds.). Statistical Ecology 1: Spatial Patterns and Statistical Distributions. Penn State University Press, Pennsylvania, pp. 337-356.

Hay, J.D., Bizerril, M.X., Calouro, A.M., Costa, E.M.N., Ferreira, A.A., Gastal, M.L.A., Goes Junior, C.D., Manzan, D.J., Martins, C.R., Monteiro, J.M.G., Oliveira, S.A., Rodrigues, M.C.M., Seyffarth, J.A.S. \& Walter, B.M.T. 2000. Comparação do padrão da distribuição espacial em escalas diferentes de espécies nativas do cerrado, em Brasília, DF. Revista Brasileira de Botânica 23: 341-347.

Hardy, O.J. \& Sonké, B. 2004. Spatial pattern analysis of tree species distribuition in a tropical rain forest of Cameroon: assessing the role of limited dispersal and niche differentiation. Forest Ecology and Management 197:191-202.

Harley, R.M. 1995. Introduction. In: B.L. Stannard (ed.). Flora of the Pico das Almas, Chapada Diamantina, Brazil. Royal Botanic Gardens, Kew, pp. 1-42.

Harper, J.L. 1990. Population Biology of plants. Academic Press, London.

Hoffmann, W.A., Solbrig, O.T. 2003. The role of topkill in the differential response of savanna woody species to fire. Forest Ecology and Management 180: 273-286. 
Hubell, S.P. 1979. Tree dispersion, abundance, and diversity in a tropical dry forest. Science 203: 1299-1309.

Hutchings, M.J. 1997. The structure of plant population. In: M.J. Crawley (ed.). Plant Ecology. 2 ed. Blackweel Science Ltd, Londres, pp. 325-358.

IBAMA - Instituto Brasileiro de Meio Ambiente. 2015. Relatório Técnico de Monitoramento do Desmatamento nos Biomas Brasileiros Por Satélite: Cerrado 2010-2011. Available in http://www.mma.gov. br/images/arquivo/80120/PPCerrado/Relatorio\%20 Tecnico_Bioma\%20Cerrado_2011vfinal.pdf (access in 04-V-2017).

INMET - Instituto Nacional de Meteriologia. 2017. Dados metereológicos da Estação Automática de Alto Paraíso de Goiás. Available in http://www.inmet.gov. br/sonabra/pg_dspDadosCodigo_sim.php?QTAyNA== (access in 25-VI-2017).

Jackson, P.C., Meinzer, F.C., Bustamante, M., Goldstein, G., Franco, A.C., Rundel, P.W., Caldas L.S., Igler, E., Causin, F. 1999. Partitioning of soil water among tree species in a Brazilian Cerrado. Tree Physiology 19: 717-724.

Janzen, D.H. 1967. Syncronization of sexual reproduction of trees within the dry season in Central América. Evolution 21: 620-637.

Janzen, D. 1970. Herbivores and the number of tree species in tropical forests. The American Naturalist 104: 501-528.

Janzen, D. H. 1980. Ecologia Vegetal nos Trópicos. Editora Pedagógica e Universitária LTDA, São Paulo.

Justiniano, M.J., Fredericksem, T.S. 2000. Phenology of tree Species in Bolivian Dry Forests. Biotropica 32: 276-281.

Kowles, P., Grant, M.C. 1983. Age and size structure analyses of Engelmann Spruce, Pondeosa Pine, Lodgepole Pine and Limber Pine in Colorado. Ecology 64: 1-9.

Krebs, C.J. 1999. Ecological Methodology. Addison Wesley Educational Publishers, Menlo Park.

Lenza, E. \& Klink, C.A. 2006. Comportamento fenológico de espécies lenhosas em um cerrado stricto sensu de Brasilia, DF. Revista Brasileira de Botânica 29: 627-638.

Lieberman, D. 1982. Seasonality and phenology in a dry tropical forest in Ghana. Journal of Ecology 70: 791-806.

Lima-Ribeiro, M.S. 2007a. Distribuição espacial de Duguetia furfuraceae (A. St.-Hil.) Benth. \& Hook. (Annonaceae) em um campo sujo no município de Caiapônia, GO, Brasil. Bioscience Journal 23: 96-104.

Lima-Ribeiro, M.S. 2007b. Distribuição espacial de espécies arbóreas em fragmentos de cerrado stricto sensu no planalto central brasileiro - GO. Biociências 15: 160-165.
Lima-Ribeiro, M.S. \& Prado, E.C. 2007. Distribuição espacial de uma população de Vernonia aurea Mart. ex DC. (Asteraceae) em um fragmento de cerradão no município de Caiapônia, GO, Brasil. Bioscience Journal 23: 81-89.

Lopes, R.M.F., Freitas, V.L.O., Barbosa, P.M.M. 2013. Estrutura do componente arbóreo em áreas de cerrado no município de São Tomé das Letras, MG. Revista Árvore 37: 801-813.

Lopez-Naranjo, H.J. 1975. Estrutura morfológica de Anacardium humile A. St.-Hil. (Anacardiaceae). Dissertação de Mestrado, Universidade de São Paulo, São Paulo.

Ludwig, J.A., Reynolds, J.F. 1988. Statistical ecology: a primer on methods and computing. John Wiley \& Sons, New York.

Lundberg, S. \& Ingvarsson, P. 1998. Population dynamics of resource limited plants and their pollinators. Theorical Population Biology 54: 44-49.

Meira Junior, M.S., Mota, S.L.L., Machado, E.L.M., Pereira, I.M. 2017. Distribuição espacial de Eremanthus incanus (Less.) Less. (Asteraceae) em duas áreas com diferentes níveis de conservação. Revista Brasileira de Biociências 15: 27-31.

Meireles, M.L. \& Luiz, A.J.B. 1995. Padrões espaciais de árvores de um cerrado em Brasília, DF. Revista Brasileira de Botânica 18: 185-189.

Miranda, I.S. 1995. Fenologia do estrato arbóreo de uma comunidade de cerrado em Alter-do-Chao, PA. Revista Brasileira de Botânica 18: 235-240.

Miranda, H.S. \& Sato, M.N. 2005. Efeitos do fogo na vegetação lenhosa do Cerrado. In: A. Scariot, J.C. Sousa-Silva, J.M. Felfili (orgs.). Cerrado: Ecologia, Biodiversidade e Conservação. Ministério do Meio Ambiente, Brasília, pp. 93-105.

Montes, R. \& Medina, E. 1977. Seasonal changes in nutrient contents of leaves of savanna trees with different ecological behaviour. Geo-Eco-Trop. Journal. 4: 295-307.

Morellato, L.P.C. 1995. As estações do ano na floresta. In: H.F. Leitão Filho \& L.P.C. Morellato (eds.). Ecologia e preservação de uma floresta tropical urbana: Reserva de Santa Genebra. Unicamp, Campinas, pp. 187-192.

Morellato, L.P.C., Leitão-Filho, H.F. 1990. Estratégias fenológicas de espécies arbóreas em floresta mesófila na Serra do Japi. Revista Brasileira de Biologia 50: 163-173.

Morellato, L.P.C. 1991. Fenologia de árvores, arbustos e lianas em uma floresta semidecídua no sudeste do Brasil. Tese de Doutorado, Universidade de Campinas, Campinas.

Murali, K.S. \& Sukumar, R. 1994. Reproductive phenology of a tropical dry forest in Mudumalai, Southern India. Journal Ecology 82: 759-767. 
Muramaki, E.A. \& Klink, A. 1996 - Efeito do fogo na dinâmica de crescimento e reprodução de Echinolaena inflexa (Poiret) Chase (Poaceae). In: H.S. Miranda, C.H. Saito, B.F.S. Dias (eds.). Impactos de queimadas em áreas de cerrado e restinga. Universidade de Brasilia, Brasília, pp. 53-60.

Nascimento, A.R.T., Longhi S.J., Brena, D.A. 2001. Estrutura e padrões de distribuição espacial de espécies arbóreas em uma amostra de floresta ombrófila mista em Nova Prata, RS. Ciência Florestal 11: 105-119.

Nathan, R. \& Muller-Landau, H.C. 2000. Spatial patterns of seed dispersal, their determinants and consequences for recruitment. Tree 15: 278-285.

Neiva, A.C.G.R., Sereno, J.R.B., Santos, S.A., Fioravanti, M.C.S. 2008. Caracterização socioeconômica e cultural da comunidade quilombola Kalunga de Cavalcante, Goiás, Brasil: dados preliminares. In: Anais do IX Simpósio Nacional do Cerrado/II Simpósio Internacional Savanas Tropicais, Parla Mundi, Brasília, pp. 1-8.

Neto, O.C.D., Lopes. A.F., Oliveira, A.P., Vale, V.S., Gusson, A.E., Schiavini, I. 2008. Estrutura de duas espécies vegetais de cerrado em área queimada e não queimada, Caldas Novas, GO. In: Anais do IX Simpósio Nacional do Cerrado/II Simpósio Internacional Savanas Tropicais, Parla Mundi, Brasília, pp. 1-8.

Neves, S.P.S. \& Conceição, A.A. 2010. Campo rupestre recém-queimado na Chapada Diamantina, Bahia, Brasil: plantas de rebrota e semente, com espécies endêmicas na rocha. Acta Botânica Brasílica 24: 697-707.

Oksanen, J., Blanchet, F. G., Kindt, R., Legendre P., O'Hara, R. B., Simpson, G. L., Solymos, P., Stevens, M. H. H., Wagner, H. 2016. Vegan: Community Ecology Package. R package version 2.4-0. Available in http://CRAN.R-project.org/package=vegan (access in 22-V-2017).

Oliveira, P.E. 1991. The pollination and reproductive biology of a cerrado woody community in Brazil. Ph.D. thesis, University of St. Andrews, St. Andrews.

Oliveira, P.E. 2008. Fenologia e biologia reprodutiva das especies de cerrado. In: S.M. Sano, S.P. Almeida, J.F. Ribeiro (eds.). Cerrado: ecologia e flora. Embrapa, Brasília, pp. 275-290.

Oliveira, P.E.A.M., Ribeiro, J.F. \& Gonzales, M.I. 1989. Estrutura e distribuição espacial de uma população de Kielmeyera coriacea Mart. de cerrados de Brasília. Revista Brasileira de Botânica 2: 39-47.

Oliveira, R.J., Mantovani, W., Melo, M.M.R.F. 2001. Estrutura do componente arbustivo-arbóreo da Floresta Atlântica de encosta, Peruíbe, SP. Acta Botânica Brasílica 15: 391-412.

Paixão, I.L.S.C. 1993. Estrutura e dinâmica de populações de espécies arbustivo-arbóreas das vertentes norte e sul do Morro da Boa Vista, Maciço da Tijuca - RJ. Tese de Doutorado, Campinas.
Paiva, R.J., Brites, R.S., Machado, R.B. 2015. The role of protected areas in the avoidance of anthropogenic conversion in a high pressure region: a matching method analysis in the core region of the Brazilian Cerrado. PloS one 10: 1-24.

Pare, S., Savadogo, P., Tigabu, M., Oden, P.C., Ouadba, J.M. 2009. Regeneration and spatial distribution of seedling populations in sudanian dry forests in relation to conservation status and human pressure. Tropical Ecology 50: 339-353.

Pirani, F.R., Sanchez, M., Pedroni, F. 2009. Fenologia de uma comunidade arbórea em cerrado stricto sensu, Barra do Garças, MT. Acta Botanica Brasilica 23: 1096-1109.

R Core Team. 2016. R: A language and environment for statistical computing, R Foundatiton for Statistical Computing, Vienna, Austria. Available in https:// www.R-project.org/ (access in 22-V- 2017).

Ramos, A.E. 1990. O efeito de queima sobre a vegetação lenhosa do Cerrado. Dissertação de Mestrado, Universidade de Brasília, Brasília.

Rawitscher, F.K., Ferri M.G., Rachid, M. 1943. Profundidade dos solos e vegetação em campos cerrados do Brasil Meridional. Anais da Academia Brasileira de Ciências 15: 267-294.

REFLORA/CNPQ. 2017. Flora do Brasil $2020 \mathrm{em}$ construção. Jardim Botânico do Rio de Janeiro. Available in http://floradobrasil.jbrj.gov.br (access in 18-VI-2017).

Rego, C.M., Negrelle, R.R.B., Morelatto, L.P.C. 2007. Fenologia: ferramenta para conservação, melhoramento e manejo de recursos vegetais arbóreos. Embrapa Florestas, Colombo.

Resende, J.C.F., Klink, C.A. \& Schiavini, I. 2003. Spatial hererogeneity and its influence on Copaifera langsdorffii Desf. (Caesalpiniaceae). Brazilian Archives of Biology and Technology 46: 405-414.

Ribeiro, J.F., Gonzalez, M.I., Oliveira, P.E.A.M., Melo, J.T. 1981. Aspectos fenológicos de espécies nativas do cerrado. In: Anais do $32^{\circ}$ Congresso Nacional de Botânica, Teresina. pp. 181-198.

Ribeiro, J.F., Castro, L.H.R. 1986. Método quantitativo para avaliar características fenológicas em árvores. Revista Brasileira de Botânica 9: 7-11.

Rocha \& Silva, E.P. 1999. Efeito do regime de queima na taxa de mortalidade e estrutura da vegetação lenhosa de campo sujo de cerrado. Dissertação de Mestrado, Universidade de Brasília, Brasília.

Sarmiento, G., Goldstein, G. \& Meinzer, F. 1985. Adaptative strategies of woody species in neotropical savannas. Biological Reviews. 60: 315-335.

Sato, M.N. 2003. Efeito a longo prazo de queimadas na estrutura da comunidade de lenhosas da vegetação do cerrado sensu stricto. Tese de Doutorado, Universidade de Brasília, Brasília. 
Schiavini, I., Resende, J. C. F., Aquino, F. G. C. 2001. Dinâmica de populações de espécies arbóreas em Mata de galeria e Mata mesófila semidecídua na margem do Ribeirão do Panga, MG. In: J.P. Ribeiro, C.E.L. Fonseca, J.C. Souza-Silva (eds.). Cerrado - Caracterização e Recuperação de Matas de Galeria. Embrapa, Planaltina, pp. 267-299.

Silvério, D.V., \& Lenza, E. 2010. Fenologia de espécies lenhosas em um cerrado típico no Parque Municipal do Bacaba, Nova Xavantina, Mato Grosso, Brasil. Biota Neotropica 10: 205-216.

Soares, M.P., Reys, P., Sá, J.L., Silva, P.O., Santos, T.M. 2014. Aspectos fenológicos de Xylopia aromatica (Lam.) Mart. (Annonaceae) em vegetação de Cerradão, Goiás, Brasil. Bioikos 28: 65-71.

Souza, J.P. \& Coimbra, F.G. 2005. Estrutura populacional e distribuição espacial de Qualea parviflora Mart. em um Cerrado sensu stricto. Bioscience Journal 21: 65-70.

Souza-Leal, T. \& Pedroso-de-Moraes, C. 2014. Fenologia reprodutiva e distribuição espacial de Oeceoclades maculata (Lindl.) Lindl. (Orchidaceae) em Cerrado do município de Mogi Guaçu, São Paulo, Brasil. Iheringia 69: 405-416.
Sposito, T.C., Santos F.A.M. 2001. Sacling of stem and crown in eight Cecropia (Cecropiaceae) species of Brazil. American Journal of Botany 88: 939-949.

Tannus, J.L., Assis, M.A., Morellato, L.P.C. 2006. Fenologia reprodutiva em campo sujo e campo úmido numa área de cerrado no sudeste do Brasil, Itirapina-SP. Biota Neotropica, 6: 1-27.

Thomas, C.D., Kunin, W.E. 1999. The spatial structure of populations. Journal of Animal Ecology, London 68: 647-657.

Vale, V.S. \& Lopes, S.F. 2010. Efeitos do fogo na estrutura populacional de quatro espécies de cerrado. Revista Nordestina de Biologia 19: 45-53.

Vasconcelos, C.C., M.A. Nicacio, J.G.L. Isacksson, W.C.S. Aparício, M.C. Guedes \& P.S. Aparício. 2011. Padrão de distribuição espacial e estrutura diamétrica da espécie Protium pallidum Cuatrec. em uma floresta de terra firme na RESEX Cajari, Amapá- Brasil. In: Anais do Simpósio Latino-Americano sobre Manejo Florestal, Santa Maria, pp. 821-827.

Weiser, V.L. \& Godoy, S.A.P. 2001. Florística em um hectare de cerrado stricto sensu na ARIE-Cerrado Pé-deGigante, Santa Rita do Passa Quatro, SP. Acta Botanica Brasilica 15: 201-212. 